,t-метр ", основаншый на выпеописанном принципе, построил Э. Рехцигель, сотрудник радиотехнического отделения Физического института ЧСАН. Прибор предназначен для исследования фотолюминофоров. Автор благодардт т. Рехцигеля за предложение схемы прибора. Подробное описание прибора будет опубликовано в подготовляемой статье.

Поступило 26. 6. 1957.

\title{
A LUMINESCENT $\tau$-METER ON A NEW PRINCIPLE
}

\author{
(Abstract of preceding paper) \\ KAREL PÁtYXK \\ Instilute of Physics, Czechosl. Acad. Sci., Prague
}

To record the exponential course of the decay or starting up of luminescence [1] use is made of instruments permitting the direct reading of the relaxation constant $\tau$, socalled $\tau$-meters. These are of two types: either an oscillograph with exponential time base [2], or a linear tinae base but taking the logarithm of the measured signal. A $\tau$-meter of the latter type has not yet been described in the literature although the methods of logarithmizing are known $[3,4,5]$. At the same time suitable use can be made of the anode characteristics of a photo-multiplier (Fig. 1), given by Eq. (1) or in a smaller range of brightness by a simpler relation (2) ( $i$ - current of photo-multiplier, $E$ - voltage on one dynode, $I$ - intensity of illumination of cathode). If we connect up the photomultiplier so that its current is constant (by change in voltage $E$ and thus amplification), Eq. (3) holds for the relation between the voltage $E$ and the illumination I. If, however, we record the voltage $E$ in this connection (block diagram in Fig. 3 ) we actually get the course $\log I$. If the course of $I(t)$ is exponential the graph of $E(t)$ is linear and the slope gives the relaxation period $\tau$ directly.

An instrument based on this principle was realized in the Institute of Physies of the Czechoslovak Academy of Sciences as a single-purpose instrument for measuring long decays of luminescent materials. The connection of the photo-multiplier, the author of which is E. Rechziegel from the department of electronics of the above Institute, is shown in Fig. 4. $\tau$ can be recorded from several seconds to several hours.

The principle is applicable in other spheres of physical measurements. If the photomultiplier is replaced by a multiplier with a heated cathode, the emission of which is put proportional e. g. to the photo-current, a $\tau$-meter is produced for the kinetics of photoconductivity; similarly when studying the kinetics of any quantities which can be transformed into an electric signal. Since this condition is satisfied practically everywhere the range of applicability of this method is considerable.

Received 26. 6. 1957.

$$
\text { Turnepamypa - References }
$$

[1] Damašlzová S., Pátek K.: Čs. čas. fys. 7 (1957), 294.

[2] Феофиллов П. П., Толстой Н. А.: ЖНЕТФ 19 (1949), 412.

[3] Atree V. H.: J. Sei. Instr. 32 (1955), 41.

Russel J.: Rev. Sci. Instr. 8 (1937), 495.

Hardy A. C.: JOSA 18 (1929), 96.

[4] Sweet M. H.: Electronics 19 (1946), 105.

[5] Hariharan P., Bhalla M. S.: JOSA 47 (1957), 378.

[6] Zworykin W.K., Ramberg E. G.: "Photoelectricity and its application", Mac Graw-Hill 1951 